\title{
Comparative Effects of Phytosterols and Plant Oils on the Growth Depression in Chicks Fed Quillaja Saponin
}

\author{
Hiroshi UEDA and Kentarou TANOUE \\ Faculty of Agriculture, Ehime University, \\ Matsuyama-shi 790-8566, Japan \\ (Received December 2, 1999 ; Accepted February 18, 2000)
}

\begin{abstract}
To compare the effect of phytosterols (PS) and plant oils on the growth depression due to saponin, seven-day-old chicks were fed experimental diets for 10-12 days. A 0.6\% Quillaja saponin in the diet depressed body weight gain, feed intake and gain/feed ratio. PS partly $(0.1-0.2 \%)$ or completely $(0.4$ or $0.6 \%$ ) counteracted the adverse effect of saponin. The effect of cholesterol (CHS) on saponin-fed chicks was compatible with that of PS. The alleviation in growth depression by both sterols was always accompanied by the increase in both feed intake and gain/feed ratio. PS also suppressed the elevated CHS concentrations in the serum and liver induced by the dietary CHS. Corn oil and coconut oil added to the saponin diet improved gain/feed ratio, but they failed to increase feed intake sufficiently. Consequently, the addition of plant oils was less effective than that of PS in alleviating the growth depressing-effect of saponin. Beef tallow, animal fat, showed the same effect on saponin-fed chicks as did plant oils. In addition, the beneficial effect of added corn oil or beef tallow disappeared when metabolizable energy of the diet containing oil or fat was equal to that of basal diet. Thus, the alleviative effect of plant oils seems to be attributed to the increase in the dietary energy rather than to the PS present in oils. In conclusion, increasing feed intake is necessary to improve the growth depression due to saponin.
\end{abstract}

Animal Science Journal 71 (3) : 261-267, 2000

Key words : Saponin, Phytosterols, Cholesterol, Oil and fat

The incorporation of higher amounts of alfalfa preparations in the diet frequently inhibits growth rates in chicks $^{1,8,11,15)}$. These effects are attributed to alfalfa saponin $^{1,11,18}$. Thus, the problem can be resolved by the use of low saponin cultivars as the material ${ }^{1,15}$.

Saponins are glycosides widely distributed in the plant kingdom and some saponins adversely affect chick growth performance ${ }^{2,8,11}$. The concurrent feeding of CHS partly or completely overcomes the growth depression due to saponins ${ }^{1,8,11,16,18,19)}$. Peterson ${ }^{10)}$ reported that the inclusion of both CHS and cottonseed oil in the diet was more effective than that of CHS alone in improving the growth-depressing effect of alfalfa saponin or Quillaja saponin (QS). $\mathrm{He}^{107}$ also reported that PS had the same effect as CHS. CHS also counteracted the fungal growth in- hibition caused by alfalfa saponin, whereas $\beta$ sitosterol, major sterol of PS, was ineffective ${ }^{3,4)}$. The result obtained with fungus conflicted with earlier observation in chicks ${ }^{10}$. However, only limited information is available concerning the effect of PS on the growth-depressing effect of saponins in animal models ${ }^{10}$.

Ueda and Shigemizu ${ }^{19)}$ observed that corn oil (CO) or coconut oil $(\mathrm{CN})$, without the concurrent addition of CHS, alleviated partly the growth depression in chicks due to tea saponin. The alleviative effect of $\mathrm{CO}$ was superior to that of $\mathrm{CN}^{19)}$, and the former contains more PS than the latter ${ }^{20)}$. Since the increase in calorie density in the diet did not affect the growth depression due to alfalfa saponin ${ }^{10}$, we have considered that the beneficial effects of plant oils may

Corresponding : Hiroshi UEDA (fax : +81 (0) 89-946-9820, e-mail : ueda@agr.ehime-u.ac.jp)

Anim. Sci. J. 71 (3) : 261-267, 2000 
Table 1. Effect of phytosterols on growth performance and cholesterol concentrations in the serum and liver of chicks (Experiment 1) ${ }^{1)}$

\begin{tabular}{ccccccc}
\hline $\begin{array}{c}\text { Cholesterol } \\
(\%)\end{array}$ & $\begin{array}{c}\text { Phytosterols } \\
(\%)\end{array}$ & $\begin{array}{c}\text { Body } \\
\text { wt gain } \\
(\mathrm{g} / 10 \mathrm{~d})\end{array}$ & $\begin{array}{c}\text { Feed intake } \\
(\mathrm{g} / 10 \mathrm{~d})\end{array}$ & $\begin{array}{c}\text { Gain/feed } \\
(\mathrm{g} / 100 \mathrm{~g})\end{array}$ & $\begin{array}{c}\text { Cholesterol } \\
\text { Serum } \\
(\mathrm{mg} / 100 \mathrm{~m} l)\end{array}$ & $\begin{array}{c}\text { Liver } \\
(\mathrm{mg} / \mathrm{g})\end{array}$ \\
\hline- & - & 79.9 & 154.0 & 51.9 & $202^{\mathrm{a}}$ & $3.8^{\mathrm{a}}$ \\
- & 1.2 & 81.1 & 154.7 & 52.5 & $199^{\mathrm{a}}$ & $3.8^{\mathrm{a}}$ \\
0.6 & - & 81.8 & 157.8 & 51.8 & $407^{\mathrm{b}}$ & $13.2^{\mathrm{b}}$ \\
0.6 & 0.6 & 80.0 & 160.0 & 50.0 & $227^{\mathrm{a}}$ & $4.0^{\mathrm{a}}$ \\
0.6 & 1.2 & 75.9 & 154.0 & 49.3 & $204^{\mathrm{a}}$ & $2.9^{\mathrm{a}}$ \\
Pooled SE & & 1.9 & 2.1 & 1.1 & 12 & 0.2 \\
\hline
\end{tabular}

1) Values are means for eight chicks. Means with different superscripts are significantly different at $\mathrm{P}<0.05$.

be attributed to PS. In the present experiment, we compared the effect of PS and plant oils on the growth depression in chicks fed $\mathrm{QS}^{7,10}$.

\section{Materials and Methods}

A day-old Single Comb White Leghorn male chicks were maintained in a room with constant temperature $\left(30^{\circ} \mathrm{C}\right)$ and continuous lighting. They were raised on a commercial chick starter ration in wire-mesh cages under a restricted pre-feeding program ${ }^{17}$. At 7 days of age, the necessary number of chicks with similar body weight was selected from the stock. They were housed individually in metabolism cages and divided into experimental groups of eight chicks each. Chicks were given free access to experimental diets and water for 10 or 12 days. At the end of the feeding experiment, chicks were deprived of feed for 5 $h$, and their body weights and feed intake were recorded. The serum and liver samples were prepared in experiment 1 by the method previously reported $^{(7)}$ to determine their CHS concentrations.

The composition of basal diets containing 20\% crude protein was as follows $(\mathrm{g} / \mathrm{kg})$; casein 209.1 , L-arginine hydrochloride 12.4, L-methionine 3.9 , glycine 4.6, choline chloride 2.0 , vitamin mixture $1.0^{17)}$, mineral mixture $65.2^{17)}$, corn oil 30.0 , cellulose 30.0 , cornstarch 200.0, and glucose 441.8 .

Effects of soybean sterols (Sigma Chemical Co., St. Louis, MO, USA) on the serum and liver CHS concentrations in chicks fed CHS and on the growth depressing-effect of QS (Sigma Chemical Co., St. Louis, MO, USA) were studied in experiments 1 and 2 , respectively. PS contains about $60 \% \beta$-sitosterol as a principal sterol. Effects of PS, CHS, CO, CN and beef tallow (BT) on the growth performance in chicks fed QS were compared in experiments 3 to 6 . Tea saponin (Woko Pure Chemical Ind., Osaka) was used in the final experiment. PS, saponins, plant oils and fat were added to the basal diet at the expense of equal amounts of glucose. Consequently, as compared with metabolizable energy (ME) of basal diet $(13.94 \mathrm{~kJ} / \mathrm{g})$, diet containing $7 \% \mathrm{CO}$ or BT had high ME (15.62 and $15.42 \mathrm{~kJ}$, respectively). In experiment $5, \mathrm{ME}$ of these diets was equalized to that of basal diet by increasing cellulose and decreasing glucose (ME-corrected diet). Following coefficients $(\mathrm{kJ} / \mathrm{g})$ were used to calculate ME; casein-amino acid mixture 16.32, plant oils 37.91 , beef tallow 35.02, cornstarch 14.64, glucose 13.85 and cellulose $0^{18)}$.

CHS concentrations in the serum and liver were measured by enzymatic procedures as reported previously ${ }^{17)}$. Statistical analysis was done using the analysis of variance, and comparisons among treatments were made by Tukey's multiple range test ${ }^{21)}$.

\section{Results}

Experiment 1 was conducted to confirm the CHSlowering effect of PS (Table 1). PS and CHS at 1.2 and $0.6 \%$ in the basal diet, respectively, did not exert any adverse effect on chick growth performance. 
Effect of Phytosterols on Saponin Toxicity

Table 2. Effect of graded levels of phytosterols on growth performance of chicks fed Quillaja saponin (Experiment 2) ${ }^{1)}$

\begin{tabular}{ccccc}
\hline $\begin{array}{c}\text { Quillaja saponin } \\
(\%)\end{array}$ & $\begin{array}{c}\text { Phytosterols } \\
(\%)\end{array}$ & $\begin{array}{c}\text { Body wt gain } \\
(\mathrm{g} / 10 \mathrm{~d})\end{array}$ & $\begin{array}{c}\text { Feed intake } \\
(\mathrm{g} / 10 \mathrm{~d})\end{array}$ & $\begin{array}{c}\text { Gain/feed } \\
(\mathrm{g} / 100 \mathrm{~g})\end{array}$ \\
\hline- & - & $91.0^{\mathrm{d}}$ & $161.3^{\mathrm{d}}$ & $56.4^{\mathrm{c}}$ \\
0.6 & - & $36.8^{\mathrm{a}}$ & $86.3^{\mathrm{a}}$ & $42.6^{\mathrm{a}}$ \\
0.6 & 0.1 & $54.6^{\mathrm{b}}$ & $115.1^{\mathrm{b}}$ & $47.4^{\mathrm{b}}$ \\
0.6 & 0.2 & $80.5^{\mathrm{c}}$ & $147.5^{\mathrm{c}}$ & $54.6^{\mathrm{c}}$ \\
0.6 & 0.4 & $85.8^{\mathrm{cd}}$ & $156.5^{\mathrm{cd}}$ & $54.8^{\mathrm{c}}$ \\
0.6 & 0.6 & $89.3^{\text {cd }}$ & $161.7^{\mathrm{d}}$ & $55.2^{\mathrm{c}}$ \\
Pooled SE & & 2.4 & 2.5 & 1.1 \\
\hline
\end{tabular}

${ }^{1}$ Values are means for eight chicks. Means with different superscripts are significantly different at $\mathrm{P}<0.05$.

Table 3. Effect of different plant oils on growth performance of chicks fed Quillaja saponin (Experiment 3) ${ }^{11}$

\begin{tabular}{|c|c|c|c|c|}
\hline Added oil & $\begin{array}{l}\text { Quillaja saponin } \\
(\%)\end{array}$ & $\begin{array}{l}\text { Body wt gain } \\
(\mathrm{g} / 10 \mathrm{~d})\end{array}$ & $\begin{array}{l}\text { Feed intake } \\
(\mathrm{g} / 10 \mathrm{~d})\end{array}$ & $\begin{array}{l}\text { Gain/feed } \\
(\mathrm{g} / 100 \mathrm{~g})\end{array}$ \\
\hline - & - & 84. $0^{\mathrm{f}}$ & $152.1^{c}$ & $55.2^{c}$ \\
\hline $7 \%$ corn oil & - & $87.9^{r}$ & $153.4^{c}$ & $57.3^{\circ}$ \\
\hline $7 \%$ coconut oil & - & $82.1^{\text {ef }}$ & $155.1^{\mathrm{F}}$ & $52.9^{\mathrm{bc}}$ \\
\hline- & 0.3 & $60.0^{c}$ & $124.5^{b}$ & $48.2^{\mathrm{b}}$ \\
\hline $7 \%$ corn oil & 0.3 & $74.1^{\text {de }}$ & $135.5^{6}$ & $54.3^{c}$ \\
\hline $7 \%$ coconut oil & 0.3 & $72.0^{d}$ & $130.3^{b}$ & $55.2^{\mathrm{c}}$ \\
\hline- & 0.6 & $31.2^{a}$ & $94.3^{a}$ & $33.1^{\mathrm{a}}$ \\
\hline $7 \%$ corn oil & 0.6 & $55.2^{\mathrm{bc}}$ & $102.2^{\mathrm{a}}$ & $54.0^{c}$ \\
\hline $7 \%$ coconut oil & 0.6 & $49.3^{6}$ & $103.2^{\mathrm{a}}$ & $47.8^{b}$ \\
\hline Pooled SE & & 2.2 & 3.5 & 1.2 \\
\hline
\end{tabular}

Addition of CHS increased the serum and liver CHS concentrations, which was completely recovered by adding 0.6 or $1.2 \%$ PS.

Effect of graded levels of PS ( 0 to $0.6 \%$ ) on the growth performance in chicks fed $0.6 \%$ QS was examined in experiment 2 (Table 2). QS decreased body weight gain, feed intake and gain/feed ratio. PS at $0.4 \%$ or more completely counteracted the adverse effect of QS.

In experiment 3, effects of $\mathrm{CO}$ and $\mathrm{CN}$ on the growth performance in chicks fed 0.3 or $0.6 \%$ QS

Anim. Sci. J. 71 (3) : 261-267, 2000 were tested (Table 3). QS depressed body weight gain, feed intake and gain/feed ratio, extent of which depended on the saponin levels in the diet. Addition of $7 \% \mathrm{CO}$ or $\mathrm{CN}$ partly overcame the adverse effect of QS. This alleviative effect was associated with the improved gain/feed ratio but not with the increase in feed intake. Both oils had comparable effect except that $\mathrm{CO}$ was superior in the gain/feed ratio in chicks fed $0.6 \%$ QS than CN.

Effects of PS, CHS, CO, BT and the various combinations with each other on the growth performance 


\section{UEDA and TANOUE}

Table 4. Effects of phytosterols (PS), cholesterol (CHS), corn oil (CO) and beef tallow (BT) on growth performance of chicks fed Quillaja saponin (Experiment 4$)^{1)}$

\begin{tabular}{|c|c|c|c|}
\hline Treatment & $\begin{array}{l}\text { Body wt gain } \\
(\mathrm{g} / 10 \mathrm{~d})\end{array}$ & $\begin{array}{l}\text { Feed intake } \\
(\mathrm{g} / 10 \mathrm{~d})\end{array}$ & $\begin{array}{c}\text { Gain/feed } \\
(\mathrm{g} / 100 \mathrm{~g})\end{array}$ \\
\hline Basal (B) & $86.3^{d}$ & $159.5^{f}$ & 54. $1^{\mathrm{cd}}$ \\
\hline $\mathrm{B}+0.6 \%$ Quillaja saponin (S) & $35.5^{a}$ & $90.4^{a}$ & $39.3^{a}$ \\
\hline $\mathrm{S}+0.1 \% \mathrm{PS}$ & $56.1^{b}$ & $113.4^{\mathrm{cd}}$ & 49. $4^{\mathrm{bc}}$ \\
\hline $\mathrm{S}+0.1 \% \mathrm{CHS}$ & $56.0^{\mathrm{b}}$ & 110. $1^{\mathrm{bcd}}$ & $50.9^{b c}$ \\
\hline $\mathrm{S}+0.2 \% \mathrm{PS}$ & 72. $1^{\text {cd }}$ & 124. $2^{\text {đe }}$ & 58. $1^{\mathrm{d}}$ \\
\hline $\mathrm{S}+0.1 \% \mathrm{PS}+0.1 \% \mathrm{CHS}$ & $75.4^{\mathrm{ed}}$ & $132.1^{\mathrm{e}}$ & 57. $4^{\mathrm{d}}$ \\
\hline $\mathrm{s}+7 \% \mathrm{CO}$ & $45.5^{\mathrm{ab}}$ & $98.0^{\mathrm{ab}}$ & 46. $4^{\mathrm{b}}$ \\
\hline $\mathrm{S}+7 \% \mathrm{BT}$ & 46. $4^{\mathrm{ab}}$ & $97.2^{\text {ab }}$ & $47.7^{b}$ \\
\hline $\mathrm{S}+0.1 \% \mathrm{PS}+7 \% \mathrm{CO}$ & $52.1^{b}$ & $105.0^{\mathrm{bc}}$ & $49.6^{\mathrm{bc}}$ \\
\hline $\mathrm{S}+0.1 \% \mathrm{PS}+7 \% \mathrm{BT}$ & $54.9^{b}$ & $108.9^{b c}$ & $50.4^{b c}$ \\
\hline Pooled SE & 2.8 & 3.1 & 1.1 \\
\hline
\end{tabular}

Table 5. Effect of dietary metabolizable energy (ME) on growth performance of chicks fed Quillaja saponin (Experiment 5) ${ }^{1)}$

\begin{tabular}{|c|c|c|c|c|c|}
\hline \multirow[b]{2}{*}{ Treatment $^{2)}$} & \multirow{2}{*}{$\begin{array}{c}\text { Body } \\
\text { wt gain } \\
(\mathrm{g} / 12 \mathrm{~d})\end{array}$} & \multicolumn{3}{|c|}{ Intake } & \multirow{2}{*}{$\begin{array}{l}\text { Gain/feed } \\
(\mathrm{g} / 100 \mathrm{~g})\end{array}$} \\
\hline & & $\begin{array}{c}\text { Feed } \\
(\mathrm{g} / 12 \mathrm{~d})\end{array}$ & $\frac{M E}{(M J / 12 d)}$ & $\begin{array}{l}\text { Protein } \\
(\mathrm{g} / 12 \mathrm{~d})\end{array}$ & \\
\hline Basal (B) & $114.3^{d}$ & $203.0^{c}$ & $2.79^{e}$ & $40.1^{c}$ & $56.3^{c}$ \\
\hline $\mathrm{B}+0.6 \%$ Quillaja saponin (S) & $43.5^{\mathrm{a}}$ & $114.8^{\mathrm{a}}$ & $1.60^{\mathrm{ab}}$ & $23.0^{\mathrm{a}}$ & 37. $9^{a}$ \\
\hline $\mathrm{S}+0.1 \%$ phytosterols & $68.5^{c}$ & $147.2^{\mathrm{b}}$ & $2.05^{\mathrm{d}}$ & $29.4^{\mathrm{b}}$ & $46.6^{b}$ \\
\hline $\mathrm{S}+7 \%$ corn oil $(\mathrm{CO})$ & $55.2^{b}$ & $120.3^{a}$ & $1.88^{\mathrm{cd}}$ & 24. $1^{\mathrm{a}}$ & $45.9^{b}$ \\
\hline $\mathrm{S}+7 \%$ beef tallow (BT) & $51.3^{\mathrm{ab}}$ & $114.5^{\mathrm{a}}$ & $1.76^{b c}$ & $22.8^{a}$ & $44.8^{b}$ \\
\hline $\mathrm{S}+7 \% \mathrm{CO}(\mathrm{ME}$ corrected $)$ & $48.7^{\mathrm{ab}}$ & $117.2^{\mathrm{a}}$ & 1. $63^{\mathrm{ab}}$ & $23.4^{\mathrm{a}}$ & $41.5^{\mathrm{ab}}$ \\
\hline $\mathrm{S}+7 \% \mathrm{BT}$ (ME corrected) & $42.3^{a}$ & $112.2^{\mathrm{a}}$ & $1.56^{\mathrm{a}}$ & $22.4^{\mathrm{a}}$ & $37.7^{\mathrm{a}}$ \\
\hline Pooled SE & 2.5 & 3.0 & 0.04 & 0.6 & 1.6 \\
\hline
\end{tabular}

${ }^{1 j}$ Values are means for eight chicks. Means with different superscripts are significantly different at $\mathrm{P}<0.05$.

2) Diets added with $\mathrm{CO}$ and $\mathrm{BT}$ at the expense of glucose contained 15.62 and $15.42 \mathrm{~kJ} \mathrm{ME} / \mathrm{g}$, respectively. $\mathrm{ME}$ of these diets was equalized (ME corrected) to that of the basal diet $(13.94 \mathrm{~kJ} / \mathrm{g})$ by adjusting glucose and cellulose in the diet.

were compared in experiment 4 (Table 4). PS at only $0.1 \%$ in the diet partly alleviated the depression in body weight gain, feed intake and gain/feed ratio in chicks fed $0.6 \%$ QS. The effect of the same level of CHS was comparable with that of PS. Increasing dietary PS level to $0.2 \%$ further increased body weight gain, feed intake and gain/feed ratio. The combined addition of $0.1 \%$ PS plus $0.1 \%$ CHS had the same effect as that of $0.2 \%$ PS. Addition of $7 \%$ $\mathrm{CO}$ or BT to the saponin diet significantly improved 
Effect of Phytosterols on Saponin Toxicity

Table 6. Effect of corn oil and beef tallow on growth performance of chicks fed Quillaja saponin (Experiment 6) ${ }^{1)}$

\begin{tabular}{llcrc}
\hline Added oil ${ }^{2)}$ & \multicolumn{1}{c}{ Saponin } & $\begin{array}{c}\text { Body } \\
\text { wt gain } \\
(\mathrm{g} / 10 \mathrm{~d})\end{array}$ & $\begin{array}{c}\text { Feed } \\
\text { intake } \\
(\mathrm{g} / 10 \mathrm{~d})\end{array}$ & $\begin{array}{c}\text { Gain/feed } \\
(\mathrm{g} / 100 \mathrm{~g})\end{array}$ \\
\hline- & - & $72.1^{\mathrm{b}}$ & $136.6^{\mathrm{b}}$ & $52.8^{\mathrm{c}}$ \\
- & $0.6 \%$ Quillaja & $32.1^{\mathrm{a}}$ & $82.8^{\mathrm{a}}$ & $38.6^{\mathrm{b}}$ \\
- & $0.6 \%$ tea & $26.5^{\mathrm{a}}$ & $87.6^{\mathrm{a}}$ & $29.9^{\mathrm{a}}$ \\
$12 \%$ corn oil & - & $78.4^{\mathrm{b}}$ & $132.6^{\mathrm{b}}$ & $59.4^{\mathrm{c}}$ \\
$12 \%$ corn oil & $0.6 \%$ Quillaja & $36.8^{\mathrm{a}}$ & $85.0^{\mathrm{a}}$ & $43.0^{\mathrm{b}}$ \\
$12 \%$ corn oil & $0.6 \%$ tea & $34.8^{\mathrm{a}}$ & $85.8^{\mathrm{a}}$ & $40.3^{\mathrm{b}}$ \\
$12 \%$ beef tallow & - & $73.3^{\mathrm{b}}$ & $132.8^{\mathrm{b}}$ & $55.3^{\mathrm{c}}$ \\
$12 \%$ beef tallow & $0.6 \%$ Quillaja & $36.0^{\mathrm{a}}$ & $82.5^{\mathrm{a}}$ & $43.7^{\mathrm{b}}$ \\
$12 \%$ beef tallow & $0.6 \%$ tea & $33.1^{\mathrm{a}}$ & $82.5^{\mathrm{a}}$ & $40.0^{\mathrm{b}}$ \\
Pooled SE & & 2.7 & 4.2 & 1.9 \\
\hline
\end{tabular}

${ }^{1)}$ Values are means for eight chicks. Means with different superscripts are significantly different at $\mathrm{P}<0.05$.

${ }^{2}$ Metabolizable energy of basal diet and those added with corn oil and beef tallow was $13.94,16.82$ and $16.48 \mathrm{~kJ} / \mathrm{g}$, respectively.

gain/feed ratio, but it did not increase feed intake. Consequently, body weight gain in QS-fed chicks increased slightly, but the difference was not significant. No change was observed when both CO and BT were simultaneously added with PS to the saponin-diet.

Effect of dietary ME level on the growth depression in chicks fed $0.6 \%$ QS was investigated in experiment 5 (Table 5). PS at $0.1 \%$ in the diet significantly improved body weight gain, which was accompanied by the increase not only in gain/feed ratio but also in feed intake as observed in experiments 3 and 4. Adding 7\% CO to the QS diet without the correction of ME significantly increased body weight gain, which was still lower than that of PS-fed chicks. BT tended to increase body weight gain, but the difference was insignificant. Gain/feed ratios in chicks fed the oil- or fat-added diets were comparable to that of PS-fed chicks. However, both diets did not increase feed intake. Equalizing $\mathrm{ME}$ in the $\mathrm{CO}$ - and BT-added diets to that of the basal diet lowered growth rate and gain/feed ratio similar to those in QS-fed chicks.

In experiment 6 , added levels of $\mathrm{CO}$ and $\mathrm{BT}$ were increased to $12 \%$ (Table 6). However, they did not improve the growth depression due to $0.6 \% \mathrm{QS}$ or tea saponin. It was reason that the additions of both oil and fat improved gain/feed ratio, but they failed to increase feed intake.

\section{Discussion}

Alfalfa saponin inhibited the growth of fungus, and CHS prevented this growth inhibition ${ }^{3,4)}$ as shown in experimental animals ${ }^{1,10,18)}$. These adverse and alleviative effects on the fungal growth were considered to be a result of the interaction of saponin and membraneal CHS $^{4,11}$. However $\beta$-sitosterol with physicochemical structure similar to CHS did not prevent the growth inhibition of the fungus due to alfalfa saponin $n^{3,4)}$. The differential effects of both sterols were explained by the different affinity for alfalfa saponin; the affinity of CHS was higher than that of $\beta$-sitosterol. Thus, CHS, but not $\beta$-sitosterol, added to the culture medium competed with the native fungal sterols and prevented the growth inhibition of fungus ${ }^{4}$.

Contrary to the result obtained with fungus ${ }^{3,4)}$, PS had the same alleviative effect as CHS on the growth depression in chicks fed QS in the present experiment as reported earlier ${ }^{10)}$. The growth depression in animals due to saponins and the alleviation by the 


\section{UEDA and TANOUE}

simultaneous addition of CHS were always accompanied by the changes in feed intake ${ }^{16,18,19)}$. Similarly, PS even at $0.1 \%$ in the diet was effective in increasing feed intake of saponin-fed chicks. The alleviative effect of CHS in saponin-fed chicks has been thought to result from the formation of unabsorbable sterol-saponin complex in the intestinal tract $^{1,11}$. Thus, animals fed both CHS and saponins increased the fecal steroid excretion and suppressed the elevation of blood CHS $^{1,9,13)}$. PS was also reported to increase fecal CHS excretion and to have the hypocholesterolemic effect in rats ${ }^{5,12)}$.

According to Peterson ${ }^{10)}$, the addition of both PS and cottonseed oil was more effective than that of PS alone in alleviating the growth depression in chicks fed alfalfa saponin, while cottonseed oil itself was ineffective. In the previous experiment ${ }^{19}, \mathrm{CO}$ and $\mathrm{CN}$, without CHS, partly overcame the growth depression due to tea saponin. Plant oils include PS at varying degrees. For instance, refined $\mathrm{CO}$ and $\mathrm{CN}$ contain about 950 and $90 \mathrm{mg}$ PS $/ 100 \mathrm{~g}^{20}$. The alleviative effect of $\mathrm{CO}$ was superior to that of $\mathrm{CN}^{19)}$. Therefore, we considered PS in plant oils as a factor alleviating the growth depression due to saponin.

The addition of $7 \% \mathrm{CO}$, calculated to provide $0.067 \%$ PS in the diet ${ }^{20)}$, to the diet containing $0.6 \%$ QS increased body weight gain, though not always significant. The increase in growth rate of saponinfed chicks by added $\mathrm{CO}$ was always accompanied by the improved gain/feed ratio. But, contrary to the effect of PS, feed intake did not increase. Consequently, the alleviative effect of $\mathrm{CO}$ was inferior to that of $0.1 \%$ PS. Although PS provided by $7 \% \mathrm{CO}$ was less than $0.1 \%$, the concurrent addition of PS and $\mathrm{CO}$ failed to increase feed intake and did not further increase body weigh gain in saponin-fed chicks. Moreover, the effect of $\mathrm{CO}$ was unexpectedly compatible with that of $\mathrm{CN}$ or animal fat (BT). In the present experiment, added oil or fat replaced the equal amounts of glucose in the basal diet, which increased dietary ME and consequently gain/feed ratio. However, when ME of the diet containing $\mathrm{CO}$ or BT was equalized to that of basal diet by adjusting glucose and cellulose levels, not only the increase in gain/feed ratio but also the beneficial effect completely disappeared.
These results indicate, as opposed to the suggestion of Petersen ${ }^{10)}$, that the alleviative effects of plant oils are attributed to the increase in ME. Peterson ${ }^{10)}$ added only $4 \%$ cottonseed oil to his diet, thus he may fail to notice the importance of calorie density in the diet. Similarly, effects of small amounts of CHS present in BT $(118 \mathrm{mg} / 100 \mathrm{~g})^{6)}$ can be negligible.

In the previous experiment ${ }^{19)}, 10 \%$ plant oils were slightly effective in counteracting the growth depression in chicks fed $0.5 \%$ tea saponin. In the last trial of this study, we added $12 \% \mathrm{CO}$ and BT to the diet containing $0.6 \%$ QS or tea saponin. However, this treatment did not counteract the growth-depressing effect of saponins. Although $\mathrm{CO}$ and BT improved gain/feed ratio, they did not increase the feed intake. Growth depression due to saponins is always associated with the decreased feed intake ${ }^{16,18,19)}$. Thus, the increase in feed intake is necessary to improve the growth depressing-effect of saponins as did PS or CHS $^{16,18,19)}$. A similar situation was observed in the growth retardation in chicks fed excess methionine; increasing dietary $\mathrm{CO}$ level up to $16 \%$ did not increase feed intake and consequently failed to alleviate the growth depression ${ }^{14}$.

\section{References}

1) Cheeke PR. Biological properties and nutritional significance of legume saponins. In : Leaf Protein Concentrates. (Telek L, Graham HD eds.) 396-414. Avi Publishing. Connecticut. 1980.

2) Fenwick DE, Oakenfull D. Saponin content of food plants and some prepared foods. Journal of Science of Food and Agriculture, 34 : 186-191. 1983.

3) Gestetner B, Assa Y, Henis Y, Birk Y, Bondi A. Lucerne saponins. IV.-Relationships between their chemical constitution, and heamolytic and antifungal activities. Journal of Science of Food and Agriculture, 22:168-172. 1971.

4) Gestetner B, Assa $Y$, Henis $Y$, Tencer $Y$, Rotman $M$, Birk Y, Bondi A. Interaction of lucerne saponins with sterols. Biochimica et Biophysica Acta, $270: 181$ 187. 1972.

5) Ikeda I, Morioka $H$, Sugano $M$. The effect of dietary $\beta$-sitosterol and $\beta$-sitostanol on the metabolism of cholesterol in rats. Agricultural and Biological Chemistry, 43 : 1927-1933. 1979.

6) Martinez VM, Newman RK, Newman CW. Barley 
diets with different fat sources have hypocholesterolemic effect in chicks. Journal of Nutrition, 122 : 1070-1076. 1992.

7) Netke SP, Scott HM, Allee, GL. Effect of excess amino acid on the utilization of the first limiting amino acid in chick diets. Journal of Nutrition, 99 : 75-81. 1969.

8) Oakenfull DG. Saponins in food-A review. Food Chemistry, $6: 19-40.1981$.

9) Oakenfull DG, Topping DL, Illman RJ, Fenwick DE. Prevention of dietary hypercholesterolaemia in the rat by soya bean and Quillaja saponins. Nutrition Reports International, 29 : 1039-1046. 1984.

10) Peterson DW. Effect of sterols on the growth of chicks fed high alfalfa diets or a diet containing Quillaja saponin. Journal of Nutrition, 42 : 597-607. 1950.

11) Price KR, Johnson IT, Fenwick GR. The chemistry and biological significance of saponins in foods and feedingstuffs. CRC Critical Reviews in Food Science and Nutrition, $26: 27-135.1987$.

12) Sugano $M$, Morioka $H$, Ikeda I. A comparison of hypocholesterolemic activity of $\beta$-sitosterol and $\beta$ sitostanol in rats. Journal of Nutrition, $107: 2011^{-}$ 2019. 1977.

13) Sugano $\mathbf{M}$, Goto $\mathrm{S}$, Yamada $\mathrm{Y}$, Yoshida K, Hashimoto Y, Matsuo T, Kimoto M. Cholesterollowering activity of various undigested fraction of soybean protein in rats. Journal of Nutrition, 120 : 977-985. 1990.
14) Ueda H, Yokota H, Tasaki I. Effect of dietary energy level on methionine toxicity in chicks. Japanese Poultry Science, $19: 9-14.1982$.

15) Ueda $\mathbf{H}$, Ohshima $\mathbf{M}$, Akitomo I. Nutritive value and hypocholesterolemic effect of alfalfa leaf protein concentrates prepared from two different varieties in chicks. Japanese Journal of Zootechnical Science, 58 : 347-355. 1987.

16) Ueda H. Effect of Gypsophila saponins on performance and plasma cholesterol concentration in chicks fed the diets different in casein content. Animal Science and Technology, 63 : 905-911. 1992.

17) Ueda H, Imanishi T, Fukumi R, Kumai S. Effect of dietary lysine and arginine addition on growth performance and serum cholesterol concentration in cholesterol-fed chicks. Animal Science and Technology, $66: 412-421.1995$.

18) Ueda H, Kakutou Y, Ohshima M. Growthdepressing effect of alfalfa saponin in chicks. Animal Science and Technology, $67: 772-779.1996$.

19) Ueda H, Shigemizu G. Effects of tea saponin, cholesterol and oils on the growth and feed passage rates in chicks. Animal Science and Technology, $69: 14-21$. 1998.

20) Weihrauch JL, Gardener JM. Sterol content of foods of plant origin. Journal of American Dietetic Association, 73 : 39-47. 1978.

21) Yoshida M. Design of Experiments for Animal Husbandry. 125-162. Yokendo. Tokyo. 1975. (in Japanese) 